\title{
Web Based-Decision Support System to Diagnose Hepatitis Disease using SAW Method
}

\author{
B. Ayshwarya, Abdul Soim, Phong Thanh Nguyen, K. Shankar, Wahidah Hashim, Satria Abadi, \\ Andino Maseleno
}

\begin{abstract}
Hepatitis is a disease caused by some types of viruses that attack and cause inflammation and damage to human liver organ cells. Liver is a very important organ of the human body that has a function as a sieve over any entry of harmful particles entering into a person's body. A person when suffering from the disease is no longer have other part of his body that can resist harmful particles or toxins into the body so that it can pose a risk of death. The quick and precise information needs of a health expert or a specialist in disease are indispensable, the treatment of Hepatitis health solution will be very helpful especially in the process of diagnosing, determining the type of hepatitis and therapies are needed. In the application of web-based technology there are several rules that are often used, one of which is the method of SAW (Simple Additive Weighting) is the calculation of the certainty level to the conclusions obtained based on the value of Probability of illness due to obviously/symptoms. The web system to be made is expected to help someone in diagnosing and determining the hepatitis suffered based on the physical symptoms.
\end{abstract}

Index Terms: hepatitis, decision support system, simple additive weighting, web

\section{INTRODUCTION}

Hepatitis is the disease of inflammation that affects the body organs that called the liver [1]. Thus is the understanding of hepatitis disease. Hepatitis itself is divided by Hepatitis A, B, and C. That's what we know in general. In fact there are also types of diseases hepatitis $\mathrm{D}$, $\mathrm{E}, \mathrm{G}$ but that type of hepatitis was not familiar for us. In order to prevent this, hepatitis is divided into two categories. Namely General and particular hepatitis prevention. Hepatitis disease is due to viruses and is largely transmitted through the blood or bodily fluids that are contaminated with this hepatitis virus then we must be really wary of the contagion of this hepatitis. Hepatitis disease is the first sequence of various liver diseases

Revised Manuscript Received on July 25, 2019.

B. Ayshwarya, Department of Computer Science, Kristu Jayanti College, Bangalore-560043, India.

Abdul Soim, Department of Information Systems, STMIK Pringsewu, Lampung, Indonesia.

Phong Thanh Nguyen, Department of Project Management, Ho Chi Minh City Open University (HCMCOU), Vietnam.

K. Shankar, School of Computing, Kalasalingam Academy of Research and Education, Krishnankoil, India.

Wahidah Hashim, Institute of Informatics and Computing Energy, Universiti Tenaga Nasional, Malaysia.

Satria Abadi, Department of Information Systems, STMIK Pringsewu, Lampung, Indonesia.

Andino Maseleno, Institute of Informatics and Computing Energy, Universiti Tenaga Nasional, Malaysia. E-mail: andimaseleno@gmail.com. throughout the world. This disease is very dangerous for life because hepatitis or the remaining symptoms are responsible for 1-2 million deaths each year. Hepatitis virus infection can develop into cirrhosis or hardening of the liver even liver cancer.

The development of technology in the field of health and new medicine can be felt in the past five years. Some guidelines and suggestions regarding treatment have begun to overwhelm the market [2-6]. Development of web system in the field of biomedical is one thing that is expected to improve the quality of human life. By transferring the expertise of a physician to diagnose the disease into a computer web program called a Web-based decision support system and with the application of the system to diagnose the Hepatitis. It is expected to help people in providing knowledge in the form of information recognizing the symptoms that arise before going to treatment. The web system programs that we present have been through step-by-step alignment, the knowledge of this web system is derived from journals, books, as well as interviews with experts in this case from doctors at the hospital of Pringsewu City, Lampung.

\section{A. Background}

- Hepatitis is a liver disorder in the form of liver cells inflammation.

- Built a decision-making system as a diagnosis of diseases to detect Hepatitis.

- The process of diagnosis using the SAW (Simple Additive Weighting) method and as its implementation media is web-based.

\section{B. The Formulation of Problem}

- Diagnose hepatitis through the application of a web system based on the input of symptoms of the disease that being suffered.

- Implement the SAW method (Simple Additive Weighting) in the process of diagnosing hepatitis.

- Using web technology as a medium to implement these symptoms into a diagnosis that is available for optimal presentation of information. 


\section{The Scope of Problem}

- Diagnose a disease based on symptoms of physical symptoms suffered.

- Diseases to be diagnosed are Hepatitis A, Hepatitis B and Hepatitis C.

- Calculations using the SAW method (Simple Additive Weighting) which shows a measure of certainty about a fact.

\section{Objective}

The paper aimed to build a system of medicine knowledge-based in diagnosing Hepatitis which can be displayed in the WEB device, so that the time efficiency and lack of public knowledge will be Resolved.

\section{E. Benefit}

This research benefit is as the first stage of the usage of web-based decision support system to diagnosis hepatitis disease for the society that is lack information.

\section{THEORETICAL BASE}

\section{A. Hepatitis}

Hepatitis is a liver disorder in the form of liver (cells) inflammation [1]. This inflammation is characterized by elevated liver enzyme levels. This increase is due to interference or damage to the liver membrane. There are two factors caused by infections and non-infectious factors. Infectious factors include hepatitis virus and bacteria. In addition to Hepatitis A, B, C, D, E, and G virus are still many other viruses that potentially cause Hepatitis e.g. adenoviruses, CMV, Herpes simplex, HIV, Rubella, varicella and others. While the bacteria that cause hepatitis include Salmonella typhi bacteria, Salmonella paratyphi, tuberculosis, Leptosvera

Non-infectious factors for example because of the drug. Certain drug may interfere with liver function and cause hepatitis.

Viruses that cause hepatitis viruses are in the human body fluid which can be transmitted at any time to others. Indeed, some people infected with this virus can heal by itself but the virus will settle in the body for lifetime.

\section{B. Hepatitis A}

The cause of the disease is a hepatitis A virus (HAV), a 27-NM-size picornavius (i.e. a virus with a positive stain RNA). The Virus is grouped into Hepatovirus, a member of the family Picornaviridae. Symptoms of hepatitis A in adults in non-endemic areas are usually characterized by fever, malaise, anorexia, nausea, abdomial disorders followed by ikterus disorder in a few days. In the developing country, Hepatitis A virus occurs in the children's age generally asymptomatic or symptoms of mild pain. Infections that occur in the age can only be examined through laboratory examination of the liver function. In large parts of the world emerged sporadically as a plague with a tendency to appear cyclically. In the developing country generally adults are already immune to these viruses so it is rare to happened. But with the improvement of environmental sanitation in large parts of the country in the world turned out to make the population of young adults become more vulnerable as the frequency occurs KLB tends to increase. In the developed country, the transmission of the disease occurs because of contact with the family environment and sexual contact with acute sufferers, and also appear sporadically in the middle age daycare places, attacking tourists traveling to the country where The disease is endemic, attacking users of injections of illegal drug addicts and homosexuals. In areas with low environmental sanitation, infections are generally occur at a very young age.

\section{Hepatitis B}

The cause of the disease is hepatitis B virus (HBV), including Hepadnavirus, measuring 42-nm double straned viral DNA with a neucleocapsid core ( $\mathrm{HBc} \mathrm{Ag}$ ) measuring $27 \mathrm{~mm}$, surrounded by a layer of lippoprotein in the outer area containing the antigen Surface (HBsAg). Only a few of them are acute hepatitis B (HVB) infections that exhibit clinical symptoms.

Less than $10 \%$ in children and $30 \%-50 \%$ in adults with acute Hepatitis B (HBV) efficiency will develop into icteric. In patients with clinical symptoms, symptoms usually insidious, and anorexia, vague abdominal disorders, nausea and vomiting, sometimes accompanied by arthralgia and trash and frequently developed into jaundice. Fever is mild or may not be at all.

Scattered around the world, endemic or seasonal variations. WHO estimates more than 2 billion people with HBV (including 350 million chronic). Each year about 1 million people die from infected $\mathrm{HBV}$ and more than 4 million clinical cases occur. In which $\mathrm{HBV}$ is endemic to high (HbsAg Prlevansi range above $8 \%$ ), infections usually occur in all ages. Although chronic infection rates are mainly caused by the occurrence of transmission during pregnancy and in infancy and children.

\section{Hepatitis C}

The cause of the disease is hepatitis $\mathrm{C}$ virus (HCV) which is an RNA virus with envelopes, classified into a different genus (Hepacavirus) from the family Flaviviridae. At least there are 6 different genotypes and more than $90 \mathrm{HCV}$ subtypes that are known right now. The symptoms of this disease are generally insidious, with anorexia, unclear abdominal disorders, nausea and vomiting, continuing to be persistent (jauncide) less often than Hepatitis B.

Although the first infection may be asymptomatic (more than $90 \%$ of cases) or mild, but most (between $50 \%-80 \%$ of cases) will be chronic. In people who are infected with chronic infections, about half of them can develop into cirrhosis or liver cancer.

This type of Hepatitis is spread throughout the world. Prevalence $\mathrm{HCV}$ is directly related to the prevalence of people who use the syringe together among drug addicts and the customs prevelence using a syringe that is not sterile in the health service.

\section{E. Decision Support System}


A decision Support System (DSS) as a computer-based system that assists in the decision making process [7-10]. DSS as a computer information system that is adaptive [11-15], interactive [16-20], flexible [21-26], which is specially developed to support the solution of unstructured management problems [27-33] to improve the quality of decision making [34-37]. Thus, one definition of DSS is an adaptive [38-42], flexible [43-47], and interactive computer-based system that is used to solve unstructured problems [48-51], by increasing the score of decisions taken [52-56].

The decision support System is a systematic approach to the nature of a problem [57-62]], the collection of the determining facts that are mature from the alternatives confronted and taking the most appropriate action [63-66].

\section{F. SAW (Simple Additive Weighting) method}

The SAW method is often also known by the weighted summation method [67][68]. The basic concept of the SAW method is finding the weighted summation of the performance rating on each alternative to all attributes. The SAW method requires the process of normalizing the decision Matrix (X) to a scale that can be compared with all existing alternative ratings.

\section{G. Overview of the Web}

Web is one of the applications that contains multimedia documents (text, images, sounds animations, video) in it that uses HTTP protocol (Hypertext Transfer Protocol) and to access them using software called the browser. Some types of current popular browsers are: Internet Explorer which is in production by Microsoft, Mozilla Firefox, and Safari which is in production by Apple.

Browser is an application that capable of running Web documents in a translation way [69-75]. The process is conducted by components contained in a browser application that is commonly called Web Engine. All Web documents are in display by the browser in a translate way.

Web sites are Web documents that are gathered into a single entity that has a Unified Resource Locator (URL) or domain and is usually publish on the Internet or intranet.

Before starting to create a Web display design, it is good to understand the function of a website, so that the design is made adapted to the function of the website. The general website has functions, namely:

- Communication function

Most websites have a communication function. Some of the facilities that provide this communication function, such as: Web base email, contact form page, chat and others.

- Information function

Website has the function of information such as news, company profile, library, reference, and others.

- Entertainment function

The Website has entertainment functions. Some examples of websites with this functionality, such as web-sites that provide online games, online music, online movies, and so on.

- Transaction function

A website can be used as a suggestion for business transactions, such as: online order, credit card payment, etc.

\section{SYSTEM ANALYSIS}

A doctor in diagnosing an illness is to see the symptoms of a patient's clinical symptoms. These symptoms are derived from the results of the questions given by the doctor to the patient, the doctor then concludes the disease suffered by the patient and how to cure it. Treatment and referral prescribed by the Doctor in accordance with the illness of the patient.

The diagnosis method of the doctor has an equation with the hepatitis Disease diagnosis model using the SAW (Simple Additive Weighting) method. Representation of doctor interpretation analysis is stated in the form of rule as a place to keep the knowledge and analysis from the doctor in the application. where two of that concluding a decision refer to a fact that the symptoms are derived. The symptoms given by the patient, in the SAW method, will be given a level of confidence that will be used to measure the certainty of a disease experienced by the patient as the doctor did.

To make a diagnosis of the web-based hepatitis disease accurately, data about the type of diseases of hepatitis, data on the symptoms of diseases, data on the type of therapy, therapeutic action data and medical record data. Medical Record Data is a file containing records and documents containing the patient's identity, examination, treatment, actions and other services that have been given. The source of data or information can be obtained from an expert, and a variety of literature about diseases, while medical record data can we get from the hospital. Here is a general overview of the diagnosis process of patients with hepatitis disease.

The Data of the diseases, symptoms, therapies, and actions obtained from medical experts and medic records will be inserted into the system for process and processed which will then be used as information of the type of hepatitis disease experienced. The process begins with creating a table of diseases, symptoms table, and table therapy along with the details, as well as the creation of medical record table.

In table of symptoms and diseases will be conducted process of counting the probability of symptoms of the disease experienced according to the record data that has been inserted into the table.

Probability score that is the reference in the calculation of SAW (Simple Additive Weighting). As for the therapy data The doctor will determine how the therapy will be applied to the disease. Table 1 shows disease and symptom. Table 2 shows diagnosis and medical record. 
Table 1. Disease and symptom

\begin{tabular}{|l|l|l|}
\hline No & \multicolumn{1}{|c|}{$\begin{array}{c}\text { Type of } \\
\text { diseases }\end{array}$} & \multicolumn{1}{c|}{ Symptoms } \\
\hline 1. & Hepatitis A & $\begin{array}{l}\text { A. Nausea in the stomach or chest } \\
\text { tightness. } \\
\text { B. Loss of appetite } \\
\text { C. Stomach discharge(vomiting) } \\
\text { D. Fatigue in body power. } \\
\text { E. Pain in the joints. }\end{array}$ \\
\hline 2. & Hepatitis B & $\begin{array}{l}\text { A. Loss of appetite. } \\
\text { B. Fatigue in body power. } \\
\text { C. Mild fever. } \\
\text { D. Jaundice }\end{array}$ \\
\hline 3. & Hepatitis C & $\begin{array}{l}\text { A. The skin and sclera of the eyes } \\
\text { are yellow. } \\
\text { B. Nausea vomiting. } \\
\text { C. defecate pale color. } \\
\text { D. Urine color like old tea. }\end{array}$ \\
\hline
\end{tabular}

Table 2. Diagnosis and medical record

\begin{tabular}{|c|l|l|}
\hline No & \multicolumn{1}{|c|}{ Diagnosis } & $\begin{array}{c}\text { Medical } \\
\text { Record }\end{array}$ \\
\hline 1. & $\begin{array}{l}\text { If there is jaundice and symptoms } \\
\text { described above, and you are worried } \\
\text { about the possibility of suffering from } \\
\text { hepatitis A, your doctor may be } \\
\text { diagnosed through blood screening. } \\
\text { It's a positive action for those who } \\
\text { suffer from acute. }\end{array}$ & Hepatitis A \\
\hline 2. & $\begin{array}{l}\text { Because the symptoms are few, most } \\
\text { people do not realize that they are } \\
\text { infected with hepatitis B. If patient } \\
\text { have been suspected of being infected } \\
\text { with hepatitis B then do blood check }\end{array}$ & Hepatitis B \\
\hline 3 & $\begin{array}{l}\text { Examination for knowing the virus } \\
\text { Hepatitis C was developed in the year } \\
\text { 1989 despite the serious researched } \\
\text { that there is still a lot to be learned } \\
\text { about this virus. Blood screening can } \\
\text { be conducted to knowing hepatitis C } \\
\text { virus. }\end{array}$ & \\
\hline
\end{tabular}

\section{IMPLEMENTATION}

The login page is the first page to be shown when opening a web diagnosis. Users must input the username and password on the login page in order to be included in the web diagnosis of hepatitis disease as shown in figure 1.
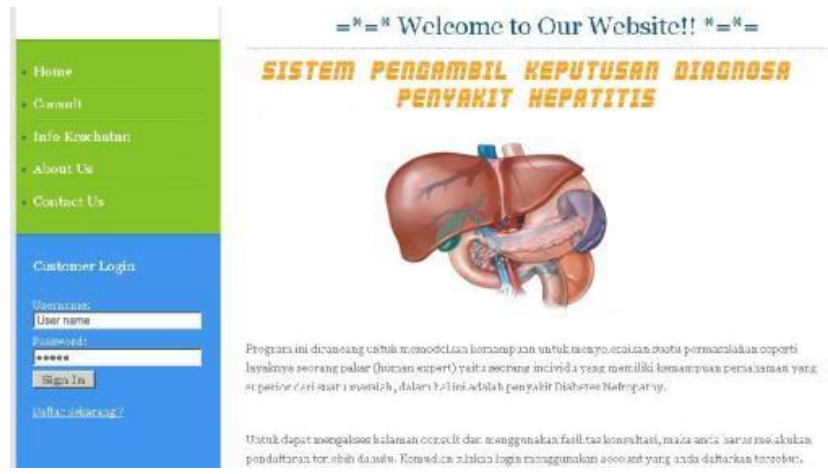

Figure 1. Login Page

Figure 2 shows display of questions to identify the symptoms experienced by the user who will do a diagnosis on the application of diagnosis of hepatitis disease.

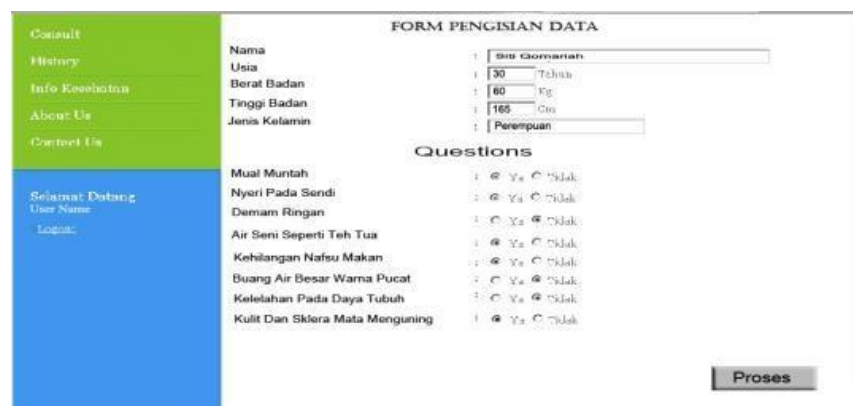

Figure 2. Symptom identification question display

The results of diagnosis conducted on the application in case 1 came to the conclusion that the results of the patient's examination of medical record with the results of diagnosis performed on the application as shown in Figure 3.
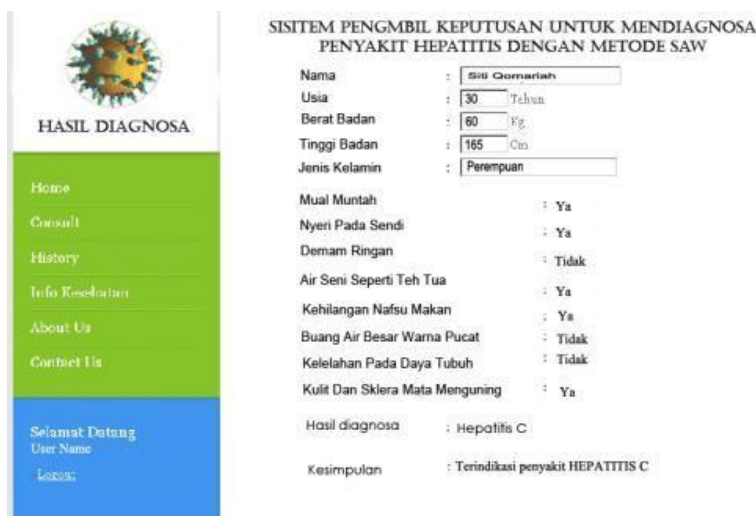

Figure 3. Diagnosis Result

\section{CONCLUSION}

Based on the results, web-based decision support system for diagnosis of hepatitis using SAW (Simple Additive Weighting) made is able to diagnose the hepatitis experienced by patients and provide certainty score to the disease suffered and produce a diagnosis data that contains about disease therapy and meal plan food menu that can help the user provide solutions to the hepatitis disease sufferer. Based on the explanation on the decision support system that has been made, there 
are some suggestions for development of this system as follows:

- The system can be developed further in terms of utilization of a media-based consultation such as Android, Blackberry, and I-Phone so it can easily access and conduct consultations.

- The system can be developed to be more complex, namely this application can be expanded area of disease that will be in the diagnosis include hepatitis disease along with the complications of diseases that accompany it.

\section{REFERENCES}

[1]. Andino Maseleno, Rohmah Zahroh Hidayati, Hepatitis Disease Detection using Bayesian Theory, The First International Conference on Mathematics, Science and Computer Science (ICMSC) 2016: Sustainability and Eco Green Innovation in Tropical Studies for Global Future, 19-21 October 2016, East Kalimantan, Indonesia. ISBN: 978-0-7354-1481-5.

[2]. Muhamad Muslihudin, G. Devika, P. Manickam, K. Shankar, Dian Permana Putra, Eki Pramudia Sukarno Putra, Miftachul Huda, Wahidah Hashim, Oksana P. Denisova, Andino Maseleno, Expert System in Determining Baby Disease using Web Mobile-based Weighted Product Method, International Journal of Recent Technology and Engineering (IJRTE), 2019. pp.3299-3308.

[3]. Muhamad Muslihudin, Siti Mukodimah, Erma Dwiyani, Trisnawati, Wahidah Hashim, Andino Maseleno, Fuzzy Logic Prediction of Dengue Hemorrhagic Fever Distribution in Pringsewu Region, International Journal of Innovative Technology and Exploring Engineering, 2019. pp.605-612.

[4]. Muhamad Muslihudin, K. Sathesh Kumar, M. Ilayaraja, K. Shankar, Lailaturrohmah, Dian Permana Putra, Wahidah Hashim, Andino Maseleno, Expert System in Determining the Quality of Nutmeg Breed using Website-Based Forward Chaining Methods, International Journal of Recent Technology and Engineering (IJRTE), 2019. pp.3309-3318.

[5]. Andino Maseleno, Md. Mahmud Hasan, Norjaidi Tuah, Charles Rangga Tabbu, Fuzzy Logic and Dempster-Shafer Theory to Predict The Risk of Highly Pathogenic Avian Influenza H5N1 Spreading, World Applied Science Journal, Vol. 34, No. 8, pp. 995-1003, 2016. ISSN: 1818-4952. doi: 10.5829/idosi.wasj.2016.34.8.15688

[6]. Andino Maseleno, Glenn Hardaker, Malaria Detection using Mathematical Theory of Evidence, Songklanakarin Journal of Science and Technology, Vol. 38, No. 3, pp. 257-263, 2016. ISSN: 0125-3395. doi:10.14456/sjst-psu.2016.35

[7]. Noca Yolanda Sari, Miftachul Huda, Kamarul Shukri Mat Teh, Anggia Sari, Ramona Ramli, Andino Maseleno, Decision support system for determining chili plant using fuzzy multiple attribute decision making, International Journal of Engineering and Technology(UAE), Vol. 7, No. 4, pp. 3556-3562, 2018.

[8]. Satria Abadi, Miftachul Huda, Kamarul Shukri Mat Teh, Zulkiflee Haron, Mohd. Nasir Ripin, Aminudin Hehsan, Shamsul Sarip, Muhamad Rafiqi Hehsan, Musfika Amrullah, Andino Maseleno, Hazard Level of Vehicle Smoke by Fuzzy Multiple Attribute Decision Making with Simple Additive Weighting Method, International Journal of Pharmaceutical Research, Vol. 10, Issue 4, 2018.

[9]. Tri Susilowati, P. Manickam, G. Devika, K. Shankar, Latifah, Muhamad Muslihudin, Wahidah Hashim, Miftachul Huda, Aleksandr Aleeksevich Korostelev, Andino Maseleno, Decision Support System for Determining Lecturer Scholarships for Doctoral Study Using CBR (Case-Based Reasoning) Method, International Journal of Recent Technology and Engineering (IJRTE), 2019. pp. 3281-3290.

[10]. Muhamad Muslihudin, M. Ilayaraja, K. Sathesh Kumar, K. Shankar, Jauharotun Jamilah, Dita Novitasari, Miftachul Huda, Wahidah Hashim, Irina V. Rudenko, Andino Maseleno, Decision Support System in Kindergarten Selection using TOPSIS Method, International Journal of Recent Technology and Engineering (IJRTE), 2019. pp.3291-3298.

[11]. Muhamad Muslihudin, S. Hemalatha, K. Shankar, Eswaran Perumal, Nofiyanti, Satria Abadi, Wahidah Hashim, Andino
Maseleno, Application of Expert System for Determining Export Quality Pepper Seeds using Website-Based Forward Chaining Method, International Journal of Recent Technology and Engineering (IJRTE), 2019. pp. 3319-3329.

[12]. Muhamad Muslihudin, Rizky Purnama, Wahidah Hashim, Andino Maseleno, Selection of Temporary Landfill using Fuzzy Multiple Attribute, International Journal of Innovative Technology and Exploring Engineering, 2019. pp.598-604.

[13]. Andino Maseleno, Miftachul Huda, Kamarul Azmi Jasmi,Bushrah Basiron, Ismail Mustari, Abdul Ghaffar Don, Roslee bin Ahmad, Hau-Kashyap Approach for Student's Level of Expertise, Egyptian Informatics Journal, Elsevier, Vol. 20, Issue 1, March 2019, pp. 27-32.

[14]. Liang Zhou, Hesam Kamyab, Aravindhan Surendar, Andino Maseleno, Aygul Z. Ibatova, Shreeshivadasan Chelliapan, Nima Karachi, Zohreh Parsaee, Novel Z-scheme composite $\mathrm{Ag} 2 \mathrm{CrO} 4 / \mathrm{NG} /$ polyimides as high performance nano catalyst for photoreduction of $\mathrm{CO} 2$ : Design, fabrication, characterization and mechanism, Journal of Photochemistry and Photobiology A: Chemistry, Elsevier, Volume 368, 1 January 2019, pp 30-40.

[15]. Muhamad Rusliyadi, Azaharaini bin $\mathrm{Hj}$. Mohd. Jamil, Marini Othman, Andino Maseleno, Ratna Tri Kumalasari, Agricultural Extension Policy, Agricultural Growth and Poverty Reduction in Indonesia, International Journal of Engineering and Technology (UAE), Vol. 7, No. 4, 2018, pp. 5539-5550.

[16]. Gunawan Budiyanto, Sri Ipnuwati, Sayyid Azam Al Gifari, Miftachul Huda, Burhanuddin Jalal, Aliza Abdul Latif, Andino Maseleno, April Lia Hananto, Web based expert system for diagnosing disease pest on banana plant, International Journal of Engineering and Technology(UAE), Vol. 7, No. 4, 2018, pp. 4715-4721.

[17]. Elisabet Yunaeti Anggraeni, Pardimin, Ihsan Dacholfany, Akla, Miftachul Huda, Kamarul Shukri Mat Teh, Aminudin Hehsan, Juhazren Junaidi, Farahwahida Mohd Yusof, Hafiza Abas, Mohd Fauzi Abu Husin, Dina Apriani, Aliza Abdul Latif, Andino Maseleno, Modelling effectivenes of IS learning methodology with AHP method, International Journal of Engineering and Technology(UAE), Vol. 7, No. 4, 2018, pp. 4708-4714.

[18]. Aditya Mulawarman, Ajat Sudrajat, Nedi Hendri, Karnawi Kamar, Dedi Mulyadi, Gunawan Budiyanto, Miftachul Huda, Aliza Abdul Latif, Andino Maseleno, FMADM for determining superior commodity at agroindustry area, International Journal of Engineering and Technology(UAE), Vol. 7, No. 4, 2018, pp. 4667-4673.

[19]. Aprianti Putri Sujana, Andri Sahata Sitanggang, Andino Maseleno, Application of E-Transport through Android-Based Ticketing Applications, Journal of Advanced Research in Dynamical and Control Systems, Issue 13-Special Issue, 2018, pp. $1347-1356$

[20]. Pardimin, Apriadi, Widhiya Ninsiana, M. Ihsan Dacholfany, Karnawi Kamar, Kamarul Shukri Mat Teh, Miftachul Huda, April Lia Hananto, Muhammad Muslihudin, K. Shankar, Natalia V. Kamenez, Andino Maseleno, Developing Multimedia Application Model for Basic Mathematics Learning, Journal of Advanced Research in Dynamical and Control Systems, Issue 14-Special Issue, 2018, pp. 1347-1356.

[21]. Natalia V. Kamenez, Olga Igorevna Vaganova, Zhanna Venediktovna Smirnova, Marina Nikolaevan Bulayeva, Ekaterina Andreevna Kuznetsova, Andino Maseleno, Experience of the use of electronic training in the educational process of the Russian higher educational institution, International Journal of Engineering and Technology(UAE), Vol. 7, No. 4, pp. 4085-4089, 2018.

[22]. Olga Igorevna Vaganova, Ludmila N. Zanfir, Zhanna Venediktovna Smirnova, Elena Aleksandrovna Chelnokova, Svetlana Nikolaevna Kaznacheeva, Andino Maseleno, On the linguistic training of future teachers of unlike specialties under the conditions of Russian professional education, International Journal of Engineering and Technology(UAE), Vol. 7, No. 4, pp. 4090-4095, 2018.

[23]. Olga Igorevna Vaganova, Natalia V. Kamenez, Vinnikova Irinia Sergeevna, Ekaterina Vladimirovna Vovk, Zhanna Venediktovna Smirnova, Andino Maseleno, Possibilities of information technologies to increase quality of educational services in Russia, International Journal of Engineering and 


\section{Web Based-Decision Support System to Diagnose Hepatitis Disease using SAW Method}

Technology(UAE), Vol. 7, No. 4, pp. 4096-4102, 2018.

[24]. Zhanna Venediktovna Smirnova, Ludmila N. Zanfir, Olga Igorevna Vaganova, Natalia Vasilevna Bystrova, Nina Vladimirovna Frolova, Andino Maseleno, WorldSkills as means of improving quality of pedagogical staff training, International Journal of Engineering and Technology(UAE), Vol. 7, No. 4, pp. 4103-4108, 2018.

[25]. Oktafianto, Ajat Sudrajat Kawangit, Razaleigh Muhamat Kawangit, Abdul Ghafar Don, Miftachul Huda, Amel Dhea Saputri,Aliza Abdul Latif, Andino Maseleno, Determining housing location using weighted product, International Journal of Engineering and Technology(UAE), Vol. 7, No. 4, pp. 3563-3568, 2018.

[26]. Fauzi, Miftachul Huda, Kamarul Shukri Mat Teh, Zulkiflee Haron, Mohd. Nasir Ripin, Aminudin Hehsan, Hafiza Abas, Muhamad Rafiq, July Irawan, Satria Abadi, Andino Maseleno, The Design of Fuzzy Expert System Implementation for Analyzing Transmissible Disease of Human, International Journal of Pharmaceutical Research, Vol. 10, Issue 4, 2018.

[27]. Mohamed Elhoseny, K. Shankar, S.K. Lakshmanaprabu, Andino Maseleno, N. Arunkumar, Hybrid Optimization with Cryptography Encryption for Medical Image Security in Internet of Things, Neural Computing and Applications, Springer, October

[28]. E. Laxmi Lydia, P. Krishna Kumar, K. Shankar, S.K Lakshmanaprabu, R.M. Vidhyavathi, Andino Maseleno, Charismatic Document Clustering through Novel K-Means Non-negative Matrix Factorization (KNMF) Algorithm using Key Phrase Extraction, International Journal of Parallel Programming, Springer, 2018, pp. 1-19.

[29]. K. Shankar, S.K. Lakshmanaprabu, Deepak Gupta, Andino Maseleno, Victor Hugo C. De Albuquerque, Optimal feature-basedmulti-kernel SVM approach for thyroid disease classification, The Journal of Supercomputing, Springer, Vol. 74, no. 259, 2018, pp. 1-16.

[30]. M. Miftakul Amin, Adi Sutrisman, Deris Stiawan, Andino Maseleno, Design Restful WebService of National Population Database for supporting E-health interoperability service, Journal of Theoretical and Applied Information Technology, vol. 96, issue 15,2018 .

[31]. A.H. Motlagh, S.V. Klyuev, Aravindhan Surendar, Aygul Z. Ibatova, Andino Maseleno, Catalytic Gasification of Oil Sludge with Calcined Dolomite, Petroleum Science and Technology, Taylor and Francis, pp. 1-5, 2018

[32]. Aravindhan Surendar, Alireza Bozorgian, Andino Maseleno, Lubov K. Ilyashenko, Meysam Najafi, Oxidation of Toxic Gases via Ge-B36N36 and Ge-C72 Nanocages as Potential Calaysts, Inorganic Chemistry Communications, Elsevier, Vol. 96, October 2018, pp. 206-210.

[33]. Abdolhamid Namdarian, Amin Goljanian Tabrizi, Andino Maseleno, Abdolkhaled Mohammadi, Seyyed Ebrahim Mossavifard, One step synthesis of rGO-Ni3S2 nano-cubes composite for high-performance supercapacitor electrodes, International Journal of Hydrogen Energy, Elsevier, vol. 43, Issue 37, 13 September 2018, pp.17780-17787.

[34]. Aravindhan Surendar, Lina G. Akhmetov, Lubov K. Ilyashenko, Andino Maseleno, Vahid Samavatian, Effect of thermal cycle loadings on mechanical properties and thermal conductivity of a porous lead-free solder joint, IEEE Transactions on Components, Packaging, and Manufacturing Technology, 2018, pp. 1769-1776.

[35]. Aravindhan Surendar, Vahid Samavatian, Andino Maseleno, Aygul Z. Ibatova, Majid Samavatian, Effect of solder layer thickness of thermo-mechanical reliability of a power electronic system, Journal of Material Science: Materials in Electronics, Springer, September 2018, Volume 29, Issue 17, pp. 15249-15258.

[36]. Majid Samavatian, Lubov K. Ilyashenko, Aravindhan Surendar, Andino Maseleno, Vahid Samavatian, Effect of System Design on Fatigue Life of Solder Joints in BGA Packages Under Vibration at Random Frequencies, Journal of Electronic Materials, November 2018, Volume 47, Issue 11, pp. 6781-6790

[37]. Ilgar Javanshir, Andino Maseleno, Shahin Tasoujian, Majid Oveisi, Optimization of suspension system of heavy off-road vehicle for stability enhancement using integrated anti-roll bar and coiling spring mechanism, Journal of Central South University, September 2018, Volume 25, Issue 9, pp 2289-2298. 2018, pp. 1-15

[38]. Andino Maseleno, Alicia Y.C. Tang, Moamin A. Mahmoud, Marini Othman, K. Shankar, Big Data and E-Learning in Education, International Journal of Computer Science and Network Security, 2018, Vol. 18, No. 5, pp. 171- 174.

[39]. Muhammad Assahubulkahfi, Yahaya Md. Sam, Andino Maseleno, Miftachul Huda, LQR Tuning by Particle Swarm Optimization of Full Car Suspension System, International Journal of Engineering and Technology(UAE), Vol. 7, No. 2.13, 2018, pp. 328-331.

[40]. Dwi Kurniasih Kamarul Azmi Jasmi, Bushrah Basiron, Miftachul Huda, Andino Maseleno, The uses of fuzzy logic method for finding agriculture and livestock value of potential village, International Journal of Engineering and Technology(UAE), Vol. 7, No. 3, 2018, pp. 1091-1095.

[41]. Hana Adela, Kamarul Azmi Jasmi, Bushrah Basiron, Miftachul Huda, Andino Maseleno, Selection of Dancer Member using Simple Additive Weighting, International Journal of Engineering and Technology(UAE), Vol. 7, No. 3, 2018, pp. 1096-1107.

[42]. Tri Susilowati, M. Ihsan Dacholfany, Sudirman Aminin, Afiful Ikhwan, Badlihisham Mohd. Nasir, Miftachul Huda, Adi Prasetyo, Andino Maseleno, Fiqih Satria, Sri Hartati, Wulandari, Getting Parents Involved in Child's School: Using Attendance Application System based on SMS Gateway, International Journal of Engineering and Technology(UAE), Vol. 7, No. 2.27, 2018, pp. 167-174.

[43]. Andino Maseleno, Alicia Y.C. Tang, Moamin A. Mahmoud, Marini Othman, Suhendi Saputra, Muhamad Muslihudin, Fuzzy AHP Method to Determine Headache Types based on Symptoms, Investigacion Clinica, Vol. 58, No. 1, 2017.

[44]. Andino Maseleno, Miftachul Huda, Maragustam Siregar, Roslee Ahmad, Aminudin Hehsan, Zulkiflee Haroon, Mohd Nasir Ripin, Siti Suhaila Ikhwani, Kamarul Azmi Jasmi, Combining the Previous Measure of Evidence to Educational Entrance Examination, Journal of Artificial Intelligence, Vol. 10, No. 3, pp. 85-90, 2017. ISSN: 2077-2173. doi: 3923/jai.2017.85.90

[45]. Miftachul Huda, Andino Maseleno, Kamarul Azmi Jasmi, Ismail Mustari, Bushrah Basiron, Strengthening Interaction from Direct to Virtual Basis: Insights from Ethical and Professional Empowerment, International Journal of Applied Engineering Research, Vol. 12, No. 17, pp. 6901-6909, 2017. ISSN: 0973-4562.

[46]. Miftachul Huda, Andino Maseleno, Masitah Shahrill, Kamarul Azmi Jasmi, Ismail Mustari, Bushrah Basiron, Exploring Adaptive Teaching Competencies in Big Data Era, International Journal of Emerging Technologies in Learning, Vol. 12, No. 3, pp. 68-83, 2017. ISSN: 1863-0383. doi: 10.3991/ijet.v12i03.6434.

[47]. Andino Maseleno, Glenn Hardaker, Noraisikin Sabani, Nabilah Suhaili, Data on multicultural education and diagnostic information profiling: Culture, learning styles and creativity, Data in Brief, Elsevier, Vol. 9, pp. 1048-1051, December 2016. doi: 10.1016/j.dib.2016.11.024.

[48]. Andino Maseleno, Md. Mahmud Hasan, Muhammad Muslihudin, Tri Susilowati, Finding Kicking Range of Sepak Takraw Game: Fuzzy Logic and Dempster-Shafer Theory Approach, Indonesian Journal of Electrical Engineering and Computer Science, Vol. 2, No. 1, pp. 187 - 193, 2016. ISSN: 2502-4752. doi: 10.11591/ijeecs.v2.i1.pp187-193

[49]. Andino Maseleno, Md. Mahmud Hasan, Norjaidi Tuah, Fauzi, Muhammad Muslihudin, Fuzzy Logic Combined with Dempster-Shafer Theory for African Trypanosomiasis Spreading Prediction, Middle-East Journal of Scientific Research, Vol. 23, No. 9, pp. 2307 - 2317, 2015. ISSN: 1990-9233, doi: 10.5829/idosi.mejsr.2015.23.09.22600

[50]. Andino Maseleno, Md. Mahmud Hasan, Norjaidi Tuah, Combining Fuzzy Logic and Dempster-Shafer Theory, TELKOMNIKA, Vol. 16, No. 3, pp. 583-590, 2015. ISSN: 2302-404. doi: 10.11591/telkomnika.v16i3.9370

[51]. Bibi Rawiyah Mulung, Andino Maseleno, Proposed SMART Traffic Control Signal in Brunei Darussalam, TELKOMNIKA, Vol. 15, No. 2, pp. 277-282, 2015. ISSN: 2302-4046. doi: 10.11591/telkomnika.v15i2.8109

[52]. P. Uma Maheswari, P. Manickam, K. Sathesh Kumar, Andino Maseleno, K. Shankar, Bat optimization algorithm 
with fuzzy based PIT sharing (BF-PIT) algorithm for Named Data Networking (NDN), Journal of Intelligent \& Fuzzy Systems, IOS Press, pp. 1-8, 2019.

[53]. Grigory Olegovich Yarygin, Aleksandr Aleeksevich Korostelev, Rafis H. Mukhutdinov, Andino Maseleno, Elections and Russian Citizens Residing Overseas: Prospects for Internet Voting, International Journal of Recent Technology and Engineering (IJRTE), Vol. 7, Issue 6S5, pp. 52-57, 2019.

[54]. Larisa Akhunzhanovna Apanasyuk, Elena Vladimirovna Smirnova, Rafis H. Mukhutdinov, Andino Maseleno, The Problem of the Organization of Socio-Cultural Environment for Adaptation and Development of a Student-Migrant's Bilingual Identity in the Conditions of the Russian Higher Education, International Journal of Recent Technology and Engineering (IJRTE), Vol. 7, Issue 6S5, pp. 63-70, 2019.

[55]. Alla L. Busygina, Liliya A. Meteleva, Darya B. Shtrikova, Rafis H. Mukhutdinov, Andino Maseleno, Bases of Formation of Women's Professional Mentality in Russia, International Journal of Recent Technology and Engineering (IJRTE), Vol. 7, Issue 6S5, pp. 71-77, 2019.

[56]. Oleg N. Yarygin, Aleksandr A. Korostelev, Linar G. Akhmetov, Andino Maseleno, Modeling of Competence as a Tool of Goal Setting for Education in Modern Society, International Journal of Recent Technology and Engineering (IJRTE), Vol. 7, Issue 6S5, pp. 78-86, 2019

[57]. Raven John, Aleksandr A. Korostelev, Oleg N. Yarygin, Rafis H. Mukhutdinov, Andino Maseleno, The Genesys and Base Concepts of Competentology, International Journal of Recent Technology and Engineering (IJRTE), Vol. 7, Issue 6S5, pp. 87-95, 2019

[58]. Bogdanova Anna Vladimirovna, Aleksandr Alekseevich Korostelev, Rafis H. Mukhutdinov, Indira A. Shakirova, Andino Maseleno, Formulation of the Problem of Mathematical Modeling of Accommodation of Basic Stations of Cellular Communication in Residential Territories for Students of It-Directions of Preparation, International Journal of Recent Technology and Engineering (IJRTE), Vol. 7, Issue 6S5, pp. 96-100, 2019.

[59]. Bogdanova A. Vladimirovna, Aleksandr A. Korostelev, Olga L. Shepelyuk, Anna E. Rodionova, Irina N. Fardeeva, Andino Maseleno, Reengineering of Business Processes of the Higher School: Its Prerequisites, International Journal of Recent Technology and Engineering (IJRTE), Vol. 7, Issue 6S5, pp. 101-104, 2019.

[60]. Rustem R. Vakhitov, Anna E. Rodionova, Elena V. Smirnova, Rafis H. Mukhutdinov, Mariya I. Arzhakova, Andino Maseleno, Crisis of Higher Education in Russia, International Journal of Recent Technology and Engineering (IJRTE), Vol. 7, Issue 6S5, pp. 105-109, 2019.

[61]. Kuznetsov Sergey Vladimirovich, Magizov Rustem Robertovich, Radzevanovskaya Yuliya Viktorovna, Alexey V. Kuznetsov, Mukhametgaliev Iskandar Gabdulvaliyevich, Andino Maseleno, Public Anti-Corruption Control as a Mechanism to Counter Corruption in the Russian Federation, International Journal of Recent Technology and Engineering (IJRTE), Vol. 7, Issue 6S5, pp. 110-113, 2019

[62]. R. Fenny Syafariani, Andri Sahata Sitanggang, Andino Maseleno, Application of Backend and Frontend Systems on Go-Baby Application in Bandung City, International Journal of Recent Technology and Engineering (IJRTE), Vol. 7, Issue 6S5, pp. 125-131, 2019

[63]. Natalia L. Ivanova, Nikolay Ivanovich Sinyavsky, Alexey Valerievich Fursov, Oksana Petrovna Denisova, Andino Maseleno, Future Oil and Gas Students' Attitude to Healthy Lifestyle and Their Participation in the Implementation of Russian Physical Educational Complex «Ready for Labor and Defense» (Rld) Normatives, International Journal of Recent Technology and Engineering (IJRTE), Vol. 7, Issue 6S5, pp. 186-189, 2019.

[64]. Natalia P. Nikonova, Larisa N. Gorina, Andino Maseleno, Cooperation between the European Union and the Eurasian Union, International Journal of Recent Technology and Engineering (IJRTE), Vol. 7, Issue 6S5, pp. 201-203, 2019.

[65]. Natalie P. Nikonova, Larisa N. Gorina, Andino Maseleno, Inter-Regional Relationship Based on Geo Economics Requirements, International Journal of Recent Technology and Engineering (IJRTE), Vol. 7, Issue 6S5, pp. 204-206, 2019.

[66]. Fenny Syafariani R., Andri Sahata Sitanggang, Eko Yudhi
Pramono, Wahidah Hashim, Andino Maseleno, Systems and Services Pattern Descriptions at Daycare, International Journal of Recent Technology and Engineering (IJRTE), Vol. 7, Issue 6S5, pp. 207-212, 2019.

[67]. Satria Abadi, Akmal Hawi, Akla, Ihsan Dacholfany, Miftachul Huda, Kamarul Shukri Mat Teh, Jaki Walidi, Wahidah Hashim, Andino Maseleno, Identification of Sundep, Leahopper and Fungus of Paddy by using Fuzzy SAW Method, International Journal of Pharmaceutical Research, Volume 11, Issue 1, January - March 2019.

[68]. Abdul Hamid, Ajat Sudrajat, Razaleigh Muhamat Kawangit, Abdul Ghafar Don, Miftachul Huda, Burhanuddin Jalal, Wahyu Akbar, Azura Onn, Andino Maseleno, Determining basic food quality using SAW, International Journal of Engineering and Technology(UAE), Vol. 7, No. 4, pp. 3548-3555, 2018.

[69]. S. Senthil, B. Ayshwarya, Prediction of Lung Cancer using Blue Whale Optimizer Algorithm with Neural Network Classifier, Journal of Advanced Research in Dynamical and Control Systems, Volume 11, 02-Special Issue, 2019. pp. 1737-1748.

[70]. Narges Bahrami, Sifeng Liu, Vadim Vitalievich Ponkratov, Phong Thanh Nguyen, Andino Maseleno, Stephen Berti, Novel Load Management for Renewable Generation Sources/Battery System through Cut Energy Expenditure and Generate Revenue, International Journal of Ambient Energy, Taylor and Francis Online, 2019.

[71]. Aravindhan Surendar, J. Muralidharan, Ali Dehghan Saee, Andino Maseleno, Aleksandr Alekseevich Rudenko, David Ros, Mathematical modelling of free convection in an ellipse-rectangular annulus filled with nanofluid using LBM, Thermal Science and Engineering Progress, Elsevier, 2019

[72]. Elena V. Smirnova, B. Ayshwarya, Phong Thanh Nguyen, Wahidah Hashim, Andino Maseleno, Using Shell Programs in Educational and Methodological Support for Learning Foreign Language, International Journal of Applied Exercise Physiology, Vol. 8 (2.1), 2019. pp. 1027-1032.

[73]. Inga E. Rakhimbaeva, Aleksandr A. Korostelev, Indira A. Shakirova, B. Ayshwarya, Phong Thanh Nguyen, Wahidah Hashim, Andino Maseleno, Integration of the Educational and Didactic Systems in the Training of Future Teachers, International Journal of Applied Exercise Physiology, Vol. 8 (2.1), 2019. pp. 1033-1038.

[74]. Alla L. Busygina, Elena M. Chertakova, Darya B. Shtrikova, B. Ayshwarya, Phong Thanh Nguyen, Wahidah Hashim, Andino Maseleno, Professional forms of Employment in the Russian Federation: Problems and Challenges, International Journal of Applied Exercise Physiology, Vol. 8 (2.1), 2019. pp. 1039-1045.

[75]. Olga I. Pugach, Andrei V. Ochepovsky, Wahidah Hashim, Andino Maseleno, B.Ayshwarya, Phong Thanh Nguyen, To the use of English Words When Learning Programming, Information Systems and Technologies, International Journal of Applied Exercise Physiology, Vol. 8 (2.1), 2019. pp. 1046-1051. 